J. Brew. Sos. Japan, Vol.76, No.8, p.561 564 (1981)

調理時の肉の特性に刘す万酾造食品の効果

に関する研宽（第 2 報）

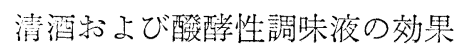

奥田和子・有坂政実・上田隆藏*

(田南女子大学, *大阪大学工学部酸醉工学科)

昭和 56 年 2 月 26 日受理

Studies on the Effects of Fermented Foods on the

Characteristics of Cooked Meat (Part 2)

On Saké and Hakkosei-chomieki

Kazuko Oruda, Masami Arisaka, and Ryuzo Ueda

(Konan Women's College)

緹䨓

清酒は家庭に乎近にあり，敃酒用せ利用できることも あって, 各種料理とくに日本扮上び回四外理に高頻度で

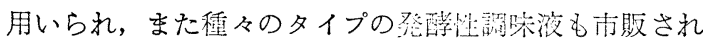
ている。著者の 1 人奥田の調查 ${ }^{1)}$ によると, 主婦が酒類 を料理に使用する整々の理由のうち，清酒では路いしく なる理由が全体の $52 \%$ を占め，一方柔くする理由は口 インよりも低かった。清酒の料理への利用例は非常に多 いけれどす, 調理科学的に解析した吥究は比㣀的少な く, 池上ら ${ }^{2)}$, 関ら ${ }^{3)}$ は炊饭時に清酒を加えた場合米飯 がかたくなることを報告している程度である。もちろ ん, その他の発酵性調味液に関する研究は㴗之んぞ行わ れていないよらである。

著者らは各種の清酒拉よび発醉性調哧液の鯨肉の特性 に及ぼす效果を比较したので報告する。

\section{実 騇 方 法}

\section{1. 譑味液の調製}

3 種類の清酒および 5 種頪の発酵性調味液をアルンー

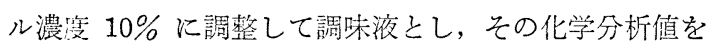
第 1 表に示した。陚料 B と C は料理用清酒, また D, E 抢よび Fは清酒タイプ， GとHはワインタイプの発醭性 謂味液で岕る。

\section{2. 著沸および漫漬条件}

まず冷谏鯨肉赤身 $1 \mathrm{~cm}^{3}$ の 17 片を, 29〜 32 $\mathrm{C}$ の温 度の調味液 $150 \mathrm{~m} l$ 点含む $300 \mathrm{~m} l$ 容ビーカーに加えて, 添加特の液温が約 $26^{\circ} \mathrm{C}$ になるようにした。ついで，ガ ス直火で沸とらさせた後さらに 10 分間保持を惹沸条件 とし，加熱せずに $26^{\circ} \mathrm{C} ， 30$ 分間保持を浸漬条件とした。 対照は水を使用した。

第 1 表 アルコール 10\%に調整した場合の試料の成分含量

陚料
$(100 \mathrm{~m} l)$




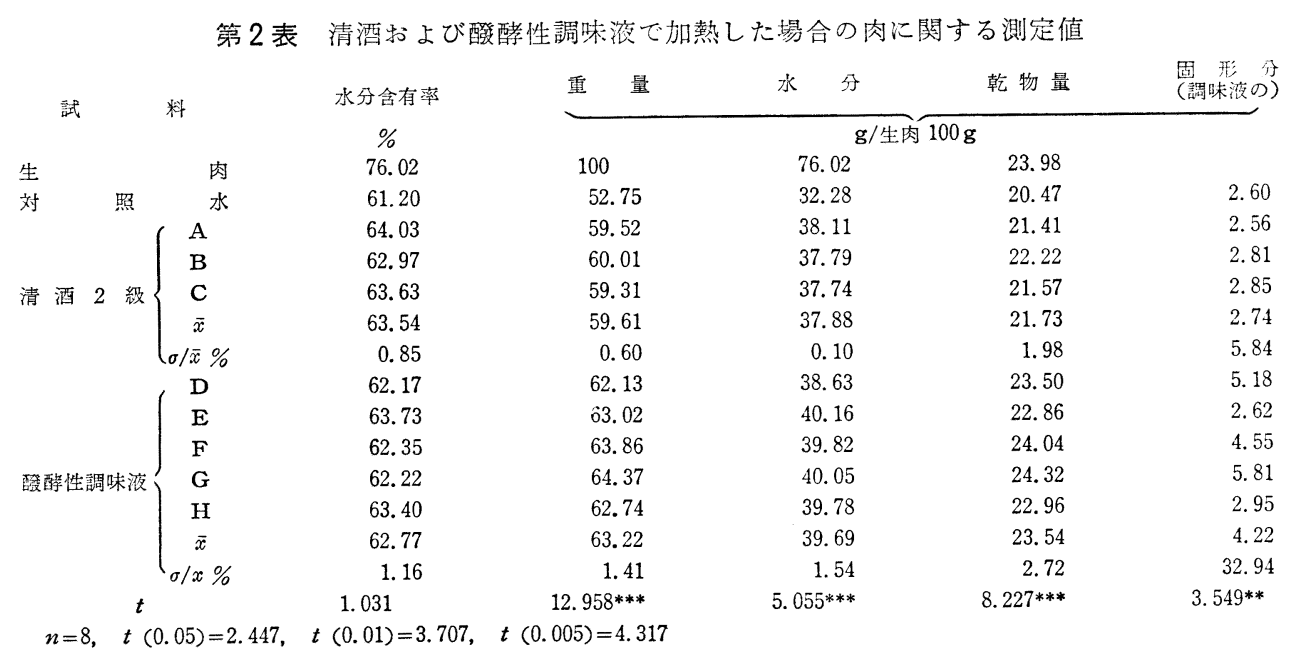

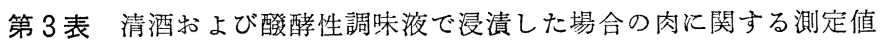

\begin{tabular}{|c|c|c|c|c|c|c|}
\hline \multirow{2}{*}{ 試 } & \multirow{2}{*}{ 料 } & \multirow{2}{*}{$\begin{array}{c}\text { 水分含有率 } \\
\%\end{array}$} & 重 & 水 & 乾物 量 & $\begin{array}{l}\text { 固 形 分 } \\
\text { (調味液の) }\end{array}$ \\
\hline & & & \multicolumn{4}{|c|}{$\mathrm{g} / 100 \mathrm{~g}$} \\
\hline 生 & 肉 & 76.60 & 100 & 76.60 & 23.40 & \\
\hline \multirow[t]{3}{*}{ 対 } & 水 & 77.71 & 88.73 & 68.95 & 19.78 & 2.98 \\
\hline & A & 76.90 & 93.62 & 71.99 & 21.63 & 2.53 \\
\hline & B & 77.28 & 93.82 & 72.50 & 21.32 & 2.45 \\
\hline \multirow[t]{6}{*}{ 清酒 2} & $\mathrm{C}$ & 76.61 & 92.77 & 71.07 & 21.70 & 3.20 \\
\hline & $\bar{x}$ & 76.93 & 93.40 & 71.85 & 21.55 & 2.73 \\
\hline & $\sigma / \bar{x} \%$ & 0.44 & 0.60 & 1.00 & 0.93 & 15.02 \\
\hline & $\mathrm{D}$ & 76.60 & 99.12 & 75.93 & 23. 19 & 5.14 \\
\hline & $\mathrm{E}$ & 77.47 & 97.71 & 75.70 & 22.01 & 4.79 \\
\hline & $\mathrm{F}$ & 76.88 & 102.92 & 79.12 & 23.80 & 8.94 \\
\hline \multirow[t]{4}{*}{ 醱酜性調味液 } & G & 76.06 & 99.55 & 75.72 & 23.83 & 8.33 \\
\hline & $\mathrm{H}$ & 76.28 & 96.26 & 73.43 & 22.83 & 4.58 \\
\hline & $\bar{x}$ & 76.66 & 99.11 & 75.98 & 23.13 & 6.36 \\
\hline & $\sigma / \bar{x} \%$ & 0.72 & 2.51 & 2.67 & 3.29 & 33.01 \\
\hline $\begin{array}{c}t \\
t<\end{array}$ & $05)=2.447$ & $\begin{array}{l}1.400 \\
t(0.005)=4.317\end{array}$ & $7.822 * * *$ & $6.227 * * *$ & 7. $524^{* * *}$ & $25.929 * * *$ \\
\hline
\end{tabular}

\section{3. 測 定方法}

鯨肉の水分含有率, 重量, 調味液中の固形分, $\mathrm{pH}$ の 測定法および水分，乾物量の算出法は前報 ${ }^{4)}$ 準じた。 調味液試料の化学分析は国税庁所定分析法注解 ${ }^{5}$ によっ た。食塩の定量は基準しょうゆ分析法に準じた。 な挑分含有率と水分との関係は下記のようである。 加熱をたは浸漬した肉の重量 $\times$ 水分含有率二水分

\section{1. 各種試料の比較}

\section{実 験 結 果}

1）加熱の場合

清酒扣よび発酵性調味液の場合の加熱後の肉の水分含 有率, 重量, 水分拈よび乾物量は第 2 表のように水のみ の場合に比べて高く, とくに重量および水分において顕 著であった。

清酒試料間の測定值の差は少なかったが発酵性調味液
では試料間の測定値の差は, やや犬きく, 水分含有率で

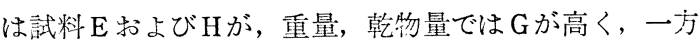

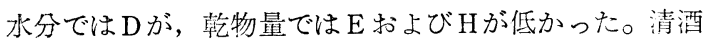
試料, 試料 $\mathrm{E}$ および $\mathrm{H}$ の固形分は $2.6 \sim 3.0 \mathrm{~g}$ の䉕国で 少なかったが，他の試料は $4.6 〜 5.8 \mathrm{~g}$ の範困にあり多 かった。

\section{2）浸漬の場合}

第 3 表のように，水のみの場合の力が，両試䉼上りも 浸漬後の水分含有率が高く, 逆に重量, 水分尔よび乾物 量はかなり低かった。

清酒の場合の浸漬後の水分含有率を除くけべての測定 值は発酵性調味液に比べて低く，また試料間の差は少な く，加熱の場合と同じ傾向が認められた。

発酵性調味液のうちでは，Fが水分含有率ざくすべ ての測定值において高く, 一方 $\mathrm{H} て ゙ は$ 重量および水分, Eでは重量および乾物量が低かった。 
第 4 表 加熱における各成分含量と肉に関する諸測定值との相関性

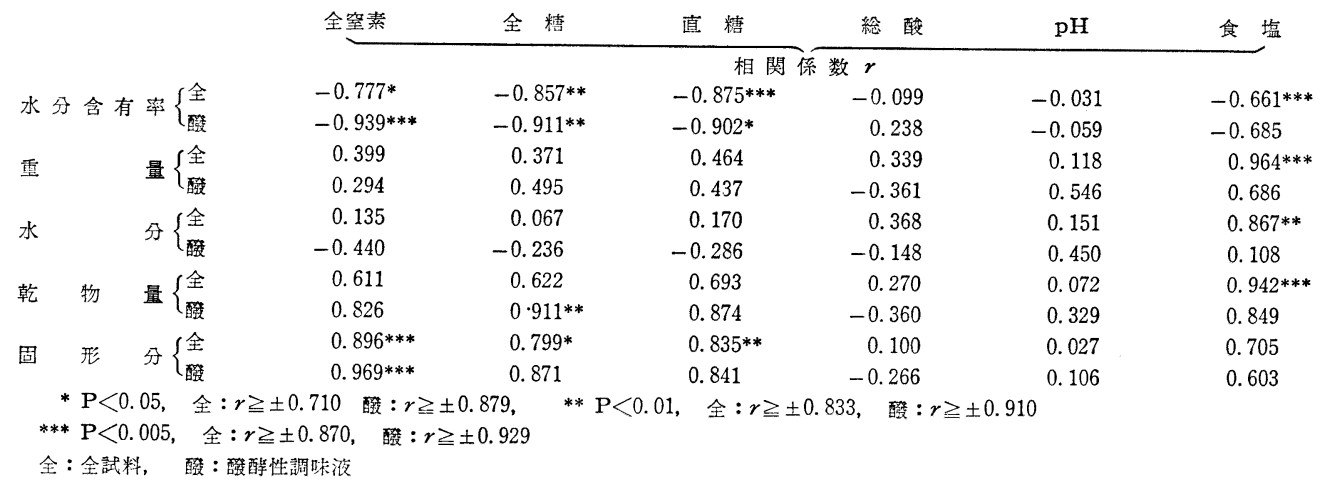

第 5 表 浸漬における各成分含量と肉に関する諸剆定值との相関性

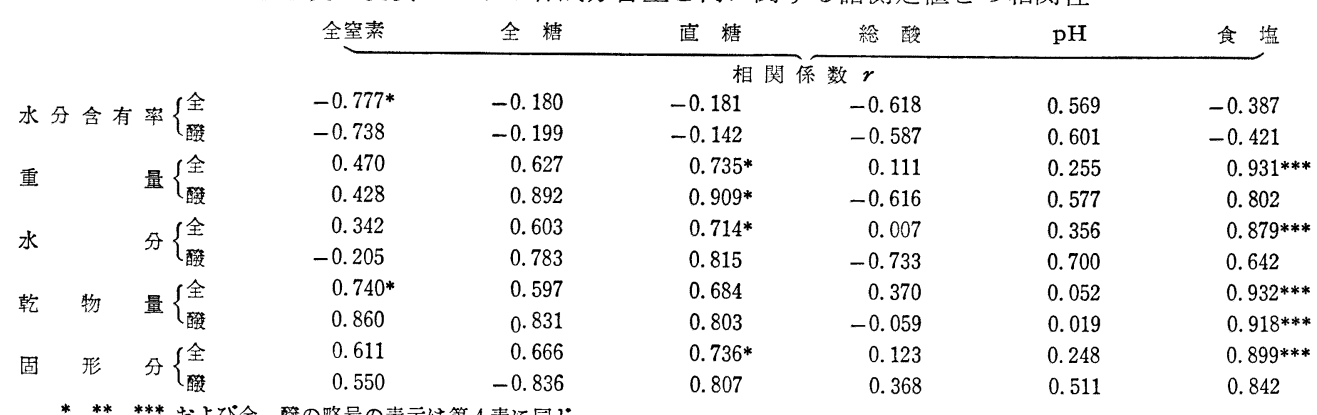

\section{2. 調味液の各成分と肉の測定值および調味液の固形 分との相関性}

加熱および浸漬における相関係数を，それぞれ第 4 表 および第 5 表に示した。清酒では, 加熱および浸漬とも に比較的相関が低かったので，結果は省略した。

1）水分含有率 加熱の場合，水分含有率は全詰料, 発酵性調味液々も, 全空素, 全糖扣よび直糖との間に有 意な負の相関が認められた。一方，浸漬の場合には，全 試料において水分含有率と全窒素の間に有意な負の相関 が羿められたにすぎなかった。

2）重量 全試料の場合, 加熱および浸漬ともに重量 は食塩との間に高度に有意な正の相関が，浸漬では直梼 との間に正の相関が認められた。一方，発酵性調味液の 場合では，浸漬において重量と全糖および直糖との間に 正の相関が認められたにすぎかなった。食塩はその他の 成分のうちでは最も高い相関係数を示したが，有意では なかった。

3）水分 全試料では，水分は食塩との間に加熱およ び浸漬ともに高度に有意な正の相関が，また浸漬におい て直糖の間に有意な正の相関が㴓められた。しかし，発 酵性調味液ではいずれの成分も有意な相関を示さなかっ た。
4）乾物量 乾物量と食塩との盟に，全試料では加熱 および浸漬ともに, 発酵性調味液では浸漬において高算 に有意な正の相関が認められた。全試料では浸漬におい て全窒素との閒に有意な正の相関が認められ，また発酵 性調味液においても加熱および浸漬ともに比䩙的高い相 関係数が得られ，同じ傾向のあることを認めた。㢹物量 と全糖との間には, 発酵性調味液では加熱において有意 な正の相関が，また浸漬においても比較的高い相関係数 が得られた。直糖との間に, 全試料に秥いて加熱で, 発 酵性調味液に扔いては加熱才よび浸漬ともに比較的高い 相関係数が得られ, 上述の全糖と同じ傾向のあることを 認めた。

5）固形分 固形分との間に，全試料の場合加熱では 全窒素, 全糖および直糖が, 浸漬では直糖おょび食塩 が，また発酵性調味液では加熱において全窒素が，有意 に正の相関のあることを認めた。な志，有意ではないが 比較的高い係数が得られたものは, 両試料ともに加熱で は全窒素, 全糖および直糖, 浸漬では全糖, 直糖および 食塩であった。

\section{考察}

前報 ${ }^{799}$ までの単一成分および多成分系モデルを用い 
た結果は, 食塩, 楉打よびカザミノ酸の単一の系では, ある濃度以上においては, 濃度が高いほど重量および䡎 物量が高く，逆に水分含有率は低くなるに対し，有機酸 のみの系ではその濃度が高い汪ど肉に関する測定值は高

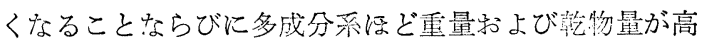
く，水分含有率が低くなる傾向のあることを示した。第 2 表祘よび第 3 表の測定値と各成分闆の有意な相関は, 上述の結果とよく符合した。なお，各成分間に有意な相 関が岉ったため，見かけ上測定值との間に有意な相関が 得られた可能性も考えられる。この点について众討した 結果, 全窒素と全糖および直糖の間飞比較的高い相関係 数（前者 0.699 , 後者 0.701) が得られたけれども, い ずれも有意な相關のないことより，その可能情のないこ とが示唆された。

得られた結果の特徵的な点の第 1 は, 全試料では, 浸 漬, 加熱ともに, 食塩は重量, 水分和上び乾物量との間 に有意な相関が喼められたにもかかわらす, 発酵性調味 液では, 浸漬において乾物量との間にのみ認められたに すぎなかったことである。発醭性調味液の場合の $\mathrm{pH}$ と 重量間の相関係数が全試料の場合よりもかなり高いこと および食塩と有機酸を舍む系では $\mathrm{pH}$ が高いほど重量が 高いことなどより考えて, 有機酸または $\mathrm{pH}$ が食塩の作 用に影響したため, 発酵性謂味液では, 食塩との相関 が, 乾物量の間にしか認められなかったものと推察され る。第 2 は全窒素が, 加熱掠よび浸漬ともに水分含有率 との閭に負の相関が認められたに対し, 全糖拉よび直糖 は加熱のみに認められ, 浸漬では認められなかったこと である。その理由については, 現在のところ明らかでは ない。第 3 は, 試料の $\mathrm{pH}$ および総酸が，それぞれ 3.15 〜4. 40 少よび 1. 40〜8.70 の箸困にあって, かなり大き なバラッキがあったにもかかわらず，両者とも，湘定值 との間には，なんら相関性が見出されなかったことであ
る。

\section{要約}

加熱および浸漬後の冷滇䇾肉の水分含有率, 画量, 水 分, 乾物量および謂味液の固形分さ3 峺颣の清酒おょび

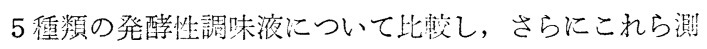
定值と調味液との成分との相関性について検討した。

加熱叔よび浸漬ともに減料间の测定健のバラッキは,

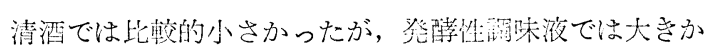

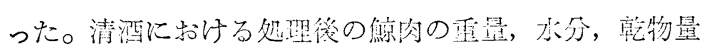

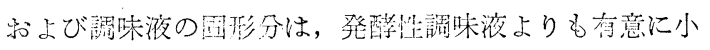
さかった。

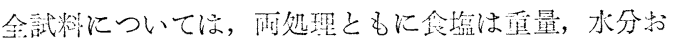

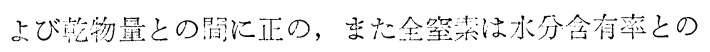

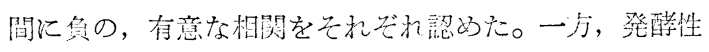
調味液では全試料で明瞭に認められた食程との上述の相

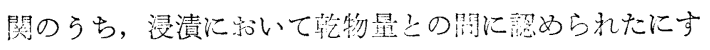
ぎなかった。また，糖と秀显との盟に正の，加熱では糖

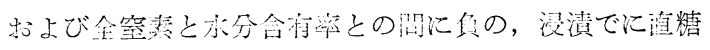

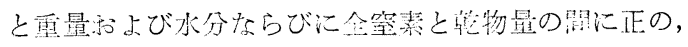

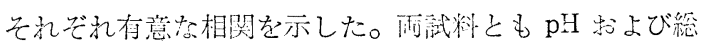

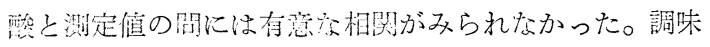

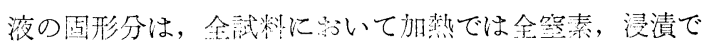

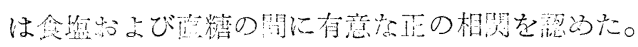

$$
\text { 文献 }
$$

1) 奥田和子，中岛教子：甲南家政，9，1 (1973)

2）池上茂了, 村田安代, 波辺信子: 家政誌，2，368 (1973)

3) 関千恵子, 貝沼やす子: 家政誌, 23. 297 (1972)

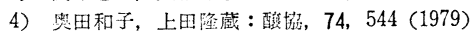

5）日本酸造拹会編：国税广前定分析法注解，6頁 (1974)

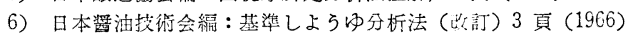

7) 奧田和子, 上田隆蔵：家政誌，28，101 (1977)

8）奧田和子, 上田隆蔵：家政志，28，188(1977)

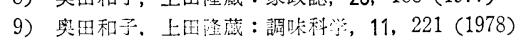

